\title{
ANÁLISE DO JULGAMENTO DA AÇÃO DIRETA DE INCONSTITUCIONALIDADE REFERENTE À CONTRIBUIÇÁO SINDICAL FACULTATIVA
}

\author{
Miriam Carla Lemos ${ }^{1}$ \\ Pontifícia Universidade Católica de Minas Gerais (PUC-MINAS)
}

Artigo recebido em: 19/04/2019

Artigo aceito em: 25/06/2019

\section{Resumo}

Este artigo propóe uma análise Para isso, a Suprema Corte poderia do julgamento da Ação Direta de atuar tanto modulando os efeitos da Inconstitucionalidade, $\mathrm{ADI}$ n. 5.794, sentença dada, a qual julgou pela não referente à contribuição sindical inconstitucionalidade dos referidos facultativa, em 2017, pela Suprema Corte. Alterada pela Lei n.13.467/2017, conhecida popularmente como Reforma Trabalhista, a abrupta mudança do sistema de financiamento dos sindicatos impactou diretamente na manutenção dos sindicatos e na assistência aos trabalhadores filiados a muitas instituições sindicais. Nesse ínterim, o presente trabalho discute, conforme instrumentos de hermenêutica jurídica, maior ativismo do Supremo Tribunal Federal para julgar em prol dos menores danos sociais. artigos da Lei, quanto pela sugestáo ao legislador para a ampliação do prazo de vacância da lei, sugerindo que seus efeitos seguissem o mesmo prazo, por exemplo, do Código de Processo Civil em 2015. O trabalho foi desenvolvido sob a metodologia jurídico-teórica e raciocínio dedutivo, com pesquisa bibliográfica e documental.

Palavras-chave: Reforma Trabalhista; Contribuição Sindical; ADI n. 5.794; Ativismo Judiciário; Modulação de sentenças; Vacatio Legis.

1 Pós-graduanda - Especialização em Direito Tributário pela PUC-MINAS. Graduada em Direito pela Escola Superior Dom Hélder Câmara (ESDHC). Graduada em Letras pela Universidade Federal de Minas Gerais (UFMG).E-mail: miriamcarlaprofessora@gmail.com 


\section{ANALYSIS OF THE JUDGMENT OF THE DIRECT ACTION OF UNCONSTITUTIONALITY REGARDING THE OPTIONAL TRADE UNION CONTRIBUTION}

\section{Abstract}

This article proposes an analysis of could act both modulating the effects of the judgment of the direct action of the sentence given, which judged by the unconstitutionality, ADI n. 5.794, referring to the voluntary union contribution in 2017, by the Supreme Court. Amended by Lawn. 13,467/2017, popularly known as Labor Reform, the abrupt change in the system of financing the trade unions had a direct impact on the maintenance of unions and on the assistance of workers affiliated with many trade union institutions. In the meantime, the present work discusses, according to instruments of legal hermeneutics, greater activism of the Federal Supreme Court to judge in favor of minor social damages. In order to do so, the Supreme Court non-unconstitutionality of the referred articles of the Law, as well as by the suggestion to the legislator to extend the term of vacancy of the law, suggesting that its effects followed the same term, for example, of the Code of Civil Procedure in 2015. The work was developed under legal-theoretical methodology and deductive reasoning, with bibliographical and documentary research.

Keywords: Labor Reform; Union Contribution; ADI n. 5,794; Judicial Activism; Modulation of sentences; Vacatio Legis.

\section{Introdução}

Após anos de economia crescente, entre 1999 e 2013, o Brasil, a partir do ano 2014, enfrentou recessão econômica devido à estagnação do PIB (produto interno bruto), o qual sofreu queda de 3,8\% em 2015 e suportou nova baixa em torno de $3 \%$ em 2016. Em razáo da crise gerada por esse panorama, a economia nacional deixou de produzir superávits primários, existentes entre os anos anteriores a 2014 e passou a enfrentar déficits primários. Diante disso, constatou-se que em 2014 o débito do setor público foi de $0,57 \%$ do PIB, em 2015 foi 1,88\%, e, em 2016, havia a expectativa de redução de $2,6 \%$ do PIB, como explicam Ferraz, Godoi e Spagnol (2017).

Perante o grave cenário de recessão econômica, o País se viu diante de um dilema para a recuperaçáo da economia: aumentar suas receitas por meio de tributos ou reduzir despesas a partir de cortes de gastos públicos. Nesse contexto, uma das opçóes do governo foi a favor dos cortes de despesas e das reformas que 
buscassem fomentar a economia. Exemplo de açóes tomadas pela administração pública na busca da reversão desse quadro foi a Emenda Constitucional 95/2016, que impôs limites aos gastos primários - educação, moradia, saúde - dos três poderes e Tribunal de Contas, Ministério Público e Defensoria Pública da União.

Em vista desse contexto, o Governo de Michel Temer passou a direcionar todos os seus planos de governabilidade no intuito de aprovar seus projetos de reforma, especialmente a trabalhista. $\mathrm{O}$ objetivo primordial da alteração era atrair investimentos para o aquecimento da economia e cortar gastos públicos. Contudo, tal reforma foi proposta de maneira a sacrificar vários direitos do trabalhador comum, conquistas advindas de grandes lutas sociais e garantidas pela Constituição da República Federativa do Brasil, de 1988.

Nessa situação política, a reforma trabalhista foi sancionada no dia 13 de julho de 2017, Lei n. 13.467/2017, e trouxe mudanças significativas na Consolidação da Legislação do Trabalho (CLT). Dentre as principais alteraçóes geradas pela reforma trabalhista no ordenamento jurídico brasileiro, pode-se destacar: alteraçóes nos períodos de férias, rescisão do contrato de trabalho de maneira mais gravosa ao empregado, aprovação de jornadas de trabalho além ou aquém do previsto na Consolidação das Leis de Trabalho, instituição da sucumbência processual. Inclui-se, nessas alteraçôes, a extinção da obrigatoriedade da contribuição sindical, tema desta pesquisa.

Em razão dos impactos provocados no sistema de arrecadação financeira dos sindicatos, entidades sindicais propuseram açóes declaratórias de inconstitucionalidade, ADIs, a fim de invalidar a nova redação dos arts. 545, 578, 579, 582, 583, 587 e 602 da CLT, alterados pela Lei n. 13.467/2017, referentes à contribuição sindical facultativa. Ao julgar a lide, o Supremo Tribunal Federal considerou que a referida alteração não feriu os preceitos constitucionais. Destarte, a mudança passou a surtir efeitos no sistema jurídico vigente.

A decisão pela constitucionalidade da alteração dos artigos foi proferida em 29 de junho de 2018, no julgamento da ADI n. 5.794 - proposta pela Confederação Nacional dos Trabalhadores em Transporte Aquaviário e Aéreo, na Pesca e nos Portos (CONTTMAF). A esta foram conexas outras dezoito açóes declaratórias de inconstitucionalidade. Por três votos contrários e seis favoráveis à manutenção da contribuição facultativa nos termos da reforma trabalhista, o Supremo Tribunal Federal, STF, decidiu que as mudanças nos artigos supramencionados eram consoantes à Constituição. Ao longo dos votos, foram debatidas a questão de a contribuição sindical ser ou não classificada como imposto - logo, compulsória - e as razóes constitucionais para a manutenção dos artigos da reforma referentes a ela. 
Entre os pontos discutidos, o ministro relator, Edson Fachin, contrário à alteração imposta, expôs que "o regime sindical estabelecido pela Constituição de 1.988 está sustentado em três pilares fundamentais: a unicidade sindical (art. $8^{\circ}$, II, da CRFB), a representatividade compulsória (art. $8^{\circ}$, III, da CRFB) e a contribuição sindical (art. 8º, IV, parte final, da CRFB)" (BRASIL, 2018b). E que, por isso, desestabilizar a base deste tripé, que possui amparo constitucional, é desestabilizar todo o regime sindical, pelo qual historicamente, os trabalhadores tanto lutaram.

Nesse sentido, o ministro relator afirmou que alterar esse sistema de contribuição de forma isolada não seria uma medida de interesse social, pois, segundo Galvão (2017 apud BRASIL, 2018b), em seu voto: "ao tocar apenas em um dos pilares da estrutura sindical, a reforma preserva uma das fontes de fragmentação e impede os sindicatos de buscar formas de organização mais eficazes para defender os direitos dos trabalhadores e resistir à ofensiva patronal". Ademais, o Estado não pode ferir o princípio da não intervenção na organização sindical (BRASIL, 2018b). Acompanharam esse posicionamento o ministro Dias Toffoli e a ministra Rosa Weber.

Em entendimento contrário, o ministro Luiz Fux apresentou o argumento que a Constituição determina que ninguém é obrigado a se filiar ou a se manter filiado a uma entidade sindical (FUX, 2018). Proposição com a qual concordaram os ministros Alexandre de Moraes, Luís Roberto Barroso, Gilmar Mendes, Marco Aurélio e Cármen Lúcia. Ademais, concluíram os ministros que o fim da contribuição sindical obrigatória não ofende as regras constitucionais.

Por esse posicionamento ser majoritário quanto à questão da contribuição sindical facultativa, restou decidida a constitucionalidade do art. 545 e congêneres, da CLT, alterados pela Lei n. 13.467/2017, sobre a contribuição sindical, que, por conseguinte, passou a ser facultativa.

Decerto a decisão de manter o caráter facultativo da arrecadação gerou consequências ao custeamento das organizaçôes sindicais, principalmente a de empregados. Entretanto, os sindicatos, além de rogarem pela declaração de inconstitucionalidade da nova legislação, poderiam também ter debatido sobre o exíguo prazo para a eficácia dela, uma das hipóteses desta pesquisa, como um pedido subsidiário, numa tentativa de conciliação de interesses e progressividade na mudança efetivada. Esse pedido justificar-se-ia porque, culturalmente, os sindicatos não são reconhecidos pelo povo como um serviço essencial, o que faz com que o custeio voluntário seja um ideal distante, especialmente em tempos de grave crise econômica, desemprego e severa perda de poder aquisitivo da população. 
Nesse contexto, os sindicatos foram descapitalizados, e, sem dinheiro, torna-se iminente o prejuízo ao cumprimento das finalidades institucionais. Assim, para além da inconstitucionalidade da norma regulamentadora, torna-se propícia a discussão sobre a forma de implantação dessa norma e as possibilidades de sentença dadas pelo Supremo Tribunal Federal para mediar a alteração e seus efeitos econômicos e sociais, segunda hipótese a ser analisada.

Portanto, por meio das discussões promovidas neste trabalho, em uma abordagem teórica, tem-se como hipótese a possibilidade de modulação dos efeitos constitucionais da novel legislação e de recomendação de alteração do prazo de vacatio legis quando proferida a sentença pela constitucionalidade da mudança. Assim, o tema-problema a ser desenvolvido ao longo do artigo é: caberia ao Supremo Tribunal Federal modular os efeitos da declaraçâo de constitucionalidade da nova lei e recomendar um novo prazo de vacância a fim de contribuir com a não descapitalizaçáo dos sindicatos? É cabível essa medida como um dos papéis institucionais do Poder Judiciário?

Por intermédio desta pesquisa, portanto, objetiva-se ampliar o debate sobre as mudanças laborais, econômicas e sociais promovidas pela legalidade da contribuição facultativa. Nesse ínterim, supõe-se que duas das alternativas possíveis para implantar a modulaçáo dos efeitos da mudança seriam alterar o prazo de vacatio legis, ao menos quanto ao período de eficácia desses artigos referentes à contribuição sindical facultativa e, também, numa posição ativista e mediadora a ser adotada pelo Supremo Tribunal Federal, utilizar as sentenças intermediárias normativas, também chamadas de transacionais, ao proferir a decisão quanto à constitucionalidade da mudança da norma.

Para tanto, seráo tomados como marcos teóricos da pesquisa as ideias propostas por Gilmar Ferreira Mendes e Paulo Gustavo Gonet Branco, na obra Curso de Direito Constitucional; Bernardo Gonçalves Fernandes, em seu Curso de Direito Constitucional e, por fim, Alfredo Bochi Brum, no artigo A "vacatio legis” posterior à Lei Complementar n. 95/98 e seus reflexos na vigência do Código Civil e da Lei n. 11.232/05.

\section{Panorama histórico da contribuição sindical no ordenamento jurídico brasileiro}

O direito trabalhista, historicamente, adveio de longo processo de conflitos entre empregadores e empregados. Apenas a título ilustrativo de tais enfrentamentos, é possível recordar a narrativa da clássica obra cinematográfica " $\mathrm{O}$ Encouraçado Potemkin”, produzido na União Soviética em 1925, pelo cineasta 
Serguei Eisenstein (1898-1948). A temática do filme é a revolução promovida pelos marinheiros do navio, homônimo da obra, contra as péssimas condiçóes de trabalho a que eram submetidos, por isso, revoltam-se e acompanham a revolução proletária que ocorria em Odessa, na Rússia Czarista, em 1905. Tal movimento ocorreu de fato e esse emblemático exemplo remete ao surgimento da consciência de classe nas relaçôes de trabalho e a importância da coletividade nas negociaçóes laborais após o início da Revolução Industrial.

Outrossim, é relevante destacar que o contexto mundial em que surgiram os direitos trabalhistas está ancorado na ruptura com o período liberal, modelo de Estado mínimo, em que as atividades financeiras do Estado limitavam-se às essenciais, como justiça, defesa e ordem interna. Devido às distorçóes típicas do liberalismo, houve significativas oscilaçóes na economia, aumento do desemprego, intensa exploração da mão de obra assalariada e crescimento das tensôes sociais. A partir disso, como resposta à crise, houve crescimento do poder e, consequentemente, da pressão dos sindicatos em exigir atuação das estruturas estatais.

Diante desse panorama, após a quebra da bolsa de Nova Iorque, em 1929, iniciou-se a construção de outra forma de Estado: o de bem-estar social, este, por sua vez, viria a se fortalecer após as duas grandes guerras mundiais. Nesse novo modelo, cabe ao Estado criar políticas públicas para concretizar direitos econômicos e sociais, visando a crescente taxa de desenvolvimento (FERRAZ; GODOI; SPANGNOL, 2017).

No Brasil, as mudanças nas relaçóes de trabalho não ocorreram de maneira diversa do momento mundial. Maurício Godinho Delgado, ao comentar sobre as alteraçóes propostas na contribuição sindical a partir da Lei n. 13.467/17, analisa a importância do estímulo às negociaçóes coletivas também a partir da vertente histórica. No período antecedente à Revolução de 1.930 , não havia institucionalização das questôes trabalhistas, como explica:

O desestímulo à negociação coletiva trabalhista era manifesto desde sempre, quer no período pré-1930, onde as questôes trabalhistas não eram sequer institucionalizadas e respeitadas, quer no período iniciado com a Revolução de 30. Vários fatores conduziam a esse desestímulo: a inexistência dos princípios cardeais da liberdade sindical e da autonomia dos sindicatos; a forte repressão aos movimentos sindicais e de greve; as dificuldades formais à celebraçáo de instrumentos coletivos negociados entấo existentes na legislação. Em contraponto a isso, a própria ordem jurídica pós-1930 favorecia claramente a propositura da ação de dissídio 
coletivo de natureza econômica para os fins de dar solução aos conflitos coletivos de trabalho (DELGADO; DELGADO, 2017, p. 50).

Como evidencia o autor, após a Revolução de 1930 questóes referentes ao direito do trabalho ganharam notoriedade. Nessa conjuntura, instituiu-se a contribuição sindical em 1939 por meio do Decreto-Lei n. 1.402, de 5 de julho do mesmo ano. Essa contribuição foi incorporada ao ordenamento jurídico brasileiro "como uma das prerrogativas dos sindicatos, a saber, a de impor contribuiçôes a todos aqueles que participam das categorias econômicas ou profissionais ou das profissóes liberais representadas"” (ANDRADE; PAVELSKI, 2017, p. 36).

Apesar de esse dispositivo implantar a compulsoriedade da contribuição sindical desde o período em que foi instituído, não determinou a forma nem o valor da arrecadação. Apenas um ano após esse evento, por meio do Decreto n. 2.377, de 8 de julho de 1.940, as condiçóes para a arrecadaçáo da contribuiçáo sindical foram estipuladas da seguinte forma:

Art. $1^{\circ}$ As contribuiçốes devidas aos sindicatos pelos que participem das categorias econômicas ou profissionais representadas pelas referidas entidades, consoante as alíneas a do art. 38 e $\mathrm{f}$ do art. $3^{\circ}$ do decreto-lei n. 1.402, de 5 de julho de 1939 (2), seráo, sob a denominação de "imposto sindical", pagas e arrecadadas pela forma estabelecida neste decreto-lei. Art. $2^{\circ} \mathrm{O}$ imposto sindical é devido, por todos aqueles que participarem de uma determinada categoria econômica ou profissional, em favor da associação profissional legalmente reconhecida como sindicato representativo da mesma categoria. Art. $3^{\circ} \mathrm{O}$ imposto sindical será pago de uma só vez, anualmente, e consistirá:

a) na importância correspondente à remuneração de um dia de trabalho, para os empregados, qualquer que seja a forma da referida remuneração; [...] (BRASIL, 1940).

Em 1943, tais critérios foram incorporados à Consolidação das Leis de Trabalho, CLT, aprovada por meio do Decreto-Lei n. 5 452, de $1^{\circ}$ de maio do referido ano.

Vinte e três anos mais tarde, o Código Tributário Nacional - Lei n. 5.172, de 25 de outubro de 1966 - alterou o nome de imposto sindical para contribuição sindical, pois o legislador entendeu que a nomenclatura "imposto sindical" estava inadequada, visto que a maior parte do valor arrecadado era destinada a entidades não estatais de acordo com a função parafiscal dos tributos, com fulcro no art. 
149 da CF; isto é, o Estado transferia a competência tributária ativa para entes sindicais, na espécie "de interesse das categorias profissionais e econômicas". A alteração ocorreu nos termos do dispositivo a seguir:

Art. 217. As disposiçóes desta Lei, notadamente as dos arts 17, $74, \$ 2^{\circ}$ e 77 , parágrafo único, bem como a do art. 54 da Lei 5.025, de 10 de junho de 1966, não excluem a incidência e a exigibilidade: (Incluído pelo Decreto-lei n. 27, de 1966)

I - da "contribuição sindical", denominação que passa a ter o imposto sindical de que tratam os arts 578 e seguintes, da Consolidação das Leis do Trabalho, sem prejuízo do disposto no art. 16 da Lei 4.589, de 11 de dezembro de 1964; (Incluído pelo Decreto-lei n. 27, de 1966) (BRASIL, 1966).

A Lei n. 4.589, de 1964, a que o art. 217 do CTN faz referência, extinguiu a Comissão do Imposto Sindical e a Comissão Técnica de orientação Sindical; criou órgãos no Ministério do Trabalho e Previdência Social, e deu outras providências. No art. 16 da Lei n. 4.589, mencionado acima, determinou-se que a permanência ou extinção do imposto sindical deveria ser discutida por uma comissão do Ministério do Trabalho e Previdência social. Ainda, no mesmo documento, no art. 22, estipulou-se a distribuição do valor arrecadado pela contribuição sindical da seguinte maneira:

Art. 22. O $\$ 2^{\circ}$ do art. 588 os arts. 590, 591, 600 e 610 da Consolidação das Leis do Trabalho (Decreto-lei n. 5.452, de 19 de maio de 1943) passam a ter a seguinte redação:

Art. 590. Das importâncias recolhidas de acôrdo com o artigo 586 o Banco do Brasil transferirá a uma conta especial denominada "Emprêgo e Salário", vinte por cento do Impôsto Sindical (BRASIL, 1966).

Assim sendo, $20 \%$ do valor arrecadado pela contribuição sindical era transferido aos cofres públicos, para financiar o Ministério do Trabalho e da Previdência social, com destinação específica para as questôes relacionadas a emprego e salário; e $20 \%$ transferido às confederaçóes. Nos termos do art.18 da mesma Lei:

Art. 18. Os vinte por cento do Imposto Sindical, que formam o "Fundo Social sindical", passarão a constituir uma conta especial denominada "Emprêgo e Salário" que será utilizada, no exercício de 1965, exclusivamente nas despesas de instalação 
e funcionamento dos órgãos criados ou transformados pela presente Lei, no pagamento do pessoal transferido dos seus cargos em comissão e funçóes gratificadas.

Parágrafo único. A partir do exercício financeiro de 1966 e enquanto vigorar o atual sistema concernente ao Impôsto Sindical, o Banco do Brasil transferirá ao Tesouro Nacional, os vinte por cento da conta especial "Emprêgo e Salário", para serem acrescidos ao orçamento do Ministério do Trabalho e Previdência social, como reforço de suas verbas ordinárias (BRASIL,1966).

Já na Constituição Federal de 1988, a compulsoriedade da contribuição sindical permaneceu interpretada com base no art. $8^{\circ}, \mathrm{IV}$ : "a assembleia geral fixará a contribuição que, em se tratando de categoria profissional, será descontada em folha, para custeio do sistema confederativo da representação sindical respectiva, independentemente da contribuição prevista em lei” (BRASIL, 1988), e no Art. 149: "Compete exclusivamente à Uniâo instituir contribuiçốes sociais, de intervenção no domínio econômico e de interesse das categorias profissionais ou econômicas, como instrumento de sua atuação nas respectivas áreas [...] (BRASIL, 1988)". Portanto, conforme a interpretação majoritária, ambos os artigos levam à conclusão que a contribuição sindical se classificava como uma espécie tributária por ser compulsória.

\subsection{A destinaçáo dos recursos arrecadados por meio da contribuiçáo sindical}

Para melhor analisar a repercussão da não obrigatoriedade da contribuição sindical após a Lei n. 13.467/2017, é mister compreender a divisão e a destinação dos recursos arrecadados, conforme a determinação da Consolidação da Leis do Trabalho, CLT. Ressalta-se, ainda, que a alteração proposta pela lei em questão ocorreu apenas quanto à facultatividade da contribuição, não afetando, assim, o critério de distribuição dos recursos arrecadados.

Art. 589. Da importância da arrecadação da contribuição sindical serão feitos os seguintes créditos pela Caixa Econômica Federal, na forma das instruçôes que forem expedidas pelo Ministro no Trabalho: I - para os empregadores: a) 5\% (cinco por cento) para a confederação correspondente; b) $15 \%$ (quinze por cento) para a federação; c) 60\% (sessenta por cento) para o sindicato respectivo; e d) $20 \%$ (vinte por cento) para a "Conta Especial Emprego e 
Salário"; II - para os trabalhadores: a) 5\% (cinco por cento) para a confederaçáo correspondente; b) $10 \%$ (dez por cento) para a central sindical; c) 15\% (quinze por cento) para a federação; d) $60 \%$ (sessenta por cento) para o sindicato respectivo; e e) $10 \%$ (dez por cento) para a "Conta Especial Emprego e Salário; [...] Art. 590. Inexistindo confederação, o percentual previsto no art. 589 desta Consolidação caberá à federação representativa do grupo. [...] $\$ 3^{\circ}$ Não havendo sindicato, nem entidade sindical de grau superior ou central sindical, a contribuição sindical será creditada, integralmente, à "Conta Especial Emprego e Salário". $\$ 4^{\circ}$ Não havendo indicação de central sindical, na forma do $\$ 1^{\circ}$ do art. 589 desta Consolidação, os percentuais que lhe caberiam serão destinados à “Conta Especial Emprego e Salário” (BRASIL, 2017a).

Conforme estipulado pela Consolidação das Leis do Trabalho, tanto a contribuição dos sindicatos patronais quanto a dos sindicatos de empregados são arrecadadas pela Caixa Econômica Federal e divididos conforme os percentuais acima descritos. Nas proporçóes definidas legalmente, os valores são distribuídos para as entidades sindicais, que são os sindicatos, as federaçóes, as confederaçôes e as centrais sindicais. Além disso, os recursos são também destinados, no percentual de 20 e de 10\%, respectivamente, para a conta Especial de Emprego e Salário. Esta, por sua vez, é administrada pelo Ministério do Trabalho e Emprego, tais valores integram os recursos do FAT (fundo de amparo ao trabalhador), em conformidade com o art. 18 da Lei n. 4.589/64:

Art. 18 Os vinte por cento do Imposto Sindical, que formam o "Fundo Social sindical", passarão a constituir uma conta especial denominada "Emprêgo e Salário" que será utilizada, no exercício de 1965, exclusivamente nas despesas de instalaçâo e funcionamento dos órgãos criados ou transformados pela presente Lei, no pagamento do pessoal transferido dos seus cargos em comissão e funçôes gratificadas.

Parágrafo único. A partir do exercício financeiro de 1966 e enquanto vigorar o atual sistema concernente ao Impôsto Sindical, o Banco do Brasil transferirá ao Tesouro Nacional, os vinte por cento da conta especial "Emprêgo e Salário", para serem acrescidos ao orçamento do Ministério do Trabalho e Previdência social, como reforço de suas verbas ordinárias (BRASIL, 1964). 
Dessa forma, a verba arrecadada por meio da contribuição sindical não se limita apenas às funçôes sindicais previstas no art. 592 da CLT, tais como assistência técnica e jurídica; assistência médica, dentária, hospitalar e farmacêutica; assistência à maternidade; bolsas de estudo e outras. Parte dos valores arrecadados também é empregada para auxiliar nas funçóes estatais exercidas pelo Ministério do Trabalho e da Previdência social para financiar o fundo de amparo ao trabalhador e outras entidades pró-trabalho, como pagamento de seguro-desemprego. Logo, a contribuição sindical também é parte da verba para o custeio e a manutenção das atividades voltadas à segurança do trabalhador por meio da transferência de recursos, é, portanto, parte integrante das receitas públicas.

\subsection{Hipótese de incidência da contribuição sindical}

A hipótese de incidência, ou fato gerador da obrigação tributária, ocorre por meio da adequação da situação de fato aos aspectos da hipótese normativa. Portanto, em se tratando da contribuiçáo sindical do empregado, qualquer trabalhador vinculado ao regime celetista enquadrado em alguma categoria profissional, antes da implementação da reforma trabalhista, era sujeito passivo da obrigação tributária; isto é, obrigado a pagá-la por meio do recolhimento obrigatório efetuado na folha de pagamento pelo empregador. Assim sendo, qualquer trabalhador estava submetido às normas antecedentes e consequentes da norma tributária.

São consideradas antecedentes da norma tributária as circunstâncias fáticas em seu caráter material, a própria essencialidade do fato: "as contribuiçóes sindicais serão pagas, recolhidas e aplicadas na forma estabelecida neste capítulo" (art. 578, CLT); temporal, "folha de pagamento relativa ao mês de março de cada ano" (art. 582, CLT) e espacial, "base territorial da entidade sindical” (art. 581, CLT). Como consequentes oriundos dessa relação têm-se o sujeito ativo, responsável pela arrecadação, os entes sindicais; o sujeito passivo, o trabalhador contribuinte, e o aspecto quantitativo, "importância correspondente à remuneraçáo de 1 (um) dia de trabalho, para os empregados, qualquer que seja a forma da referida remuneração" (art. 580, CLT).

Com o advento da Lei n. 13.467/2017 a contribuição sindical perdeu o caráter compulsório e, consequentemente, a natureza tributária. Consoante o art. $3^{\circ}$ do Código Tributário Nacional (CTN), "Tributo é toda prestação pecuniária compulsória, em moeda ou cujo valor nela se possa exprimir, que náo constitua sanção de ato ilícito, instituída em lei e cobrada mediante atividade administrativa plenamente vinculada" (BRASIL, 1966). A contribuiçâo sindical, nesse ínterim, 
enquadrava-se na definição do CTN, pois era uma prestação pecuniária, paga em dinheiro, a toda evidência, sem caráter sancionatório, prevista em lei e cobrada compulsoriamente, no mês de março de todos os anos calendários para os trabalhadores e em outros meses, também definidos em lei, para contribuintes empregadores e autônomos.

No entanto, conforme a nova redação do art. 545 e seguintes da CLT "os empregadores ficam obrigados a descontar da folha de pagamento dos seus empregados, desde que por eles devidamente autorizados, as contribuiçóes devidas ao sindicato, quando por este notificados" (BRASIL 2017a). Destarte, uma vez que o desconto da contribuição sindical passa a ser efetivado apenas mediante autorização do empregado, a obrigação deixa de ser compulsória, consequentemente, deixa de ser tributária, não se enquadrando mais na definição do art. $3^{\circ}$ do CTN.

Na concepção de Delgado, com a mudança promovida pela reforma trabalhista, houve aviltamento das condições de negociação coletiva para o trabalho. Esse pensamento se justifica, visto que sem o caráter compulsório a tendência natural é a redução da quantia dos valores arrecadados a título de contribuição sindical. Isso, segundo o autor, teleologicamente é inconstitucional, pois a Carta Magna de 1988 tem como máximo norteador o princípio da dignidade humana e este é, entre outros fatores, atrelado ao trabalho. Conforme explica:

Afinal, a negociação coletiva trabalhista consiste em um instrumento de democratizaçáo do poder e da riqueza no âmbito da sociedade civil; é importante veículo institucionalizado para a busca da maior democratização e inclusão socioeconômica das pessoas humanas na sociedade civil. Entretanto, se não exercer esse papel - ao invés, passando a se transmutar em mecanismo de rebaixamento das condiçôes de vida e trabalho da pessoa humana trabalhadora -, ela se encontrará desfigurada, descaracterizada, posta distante de sua função histórica, lógica e teleológica no Direito Coletivo do Trabalho. Ora, a Constituiçâo da República, conforme já dito neste livro, resgatou a negociaçăo coletiva de seu limbo jurídico e de sua inércia factual, que eram uma das marcas distintivas, nesse campo, do período precedente a 1988. Mas não a transformou, perversamente, em um mecanismo adicional de solapamento de direitos individuais e sociais humanísticos trabalhistas - os quais a própria Constituição de 1988 alçou a patamar magno e superior (DELGADO; DELGADO, 2017, p. 252). 
Assim como o renomado autor defende a inconformidade constitucional entre a mudança promovida pela nova lei e a Carta Magna, diversas instituiçóes sindicais também interpretaram como equívoca a alteração quanto à constitucionalidade da norma. Assim, diante das interpretaçôes sobre a alteração no mecanismo de cobrança da contribuição sindical, dezenove açôes diretas de inconstitucionalidade foram propostas perante o Supremo Tribunal Federal, órgão competente para julgá-las.

\section{Ação Declaratória de Constitucionalidade n. 5.794}

Ação declaratória de constitucionalidade é um instrumento de controle normativo abstrato. Formalizada pela Emenda Constitucional n. 03/93, é concebida nos casos de relevante controvérsia judicial quanto à constitucionalidade de lei ou ato normativo federal. Por força constitucional, seu julgamento é de competência do Supremo Tribunal Federal, conforme preceitua o art. 102, I, "a", segunda parte, da Constituição Federal de 1988:

Art. 102. Compete ao Supremo Tribunal Federal, precipuamente, a guarda da Constituição, cabendo-lhe: I - processar e julgar, originariamente:

a) a açáo direta de inconstitucionalidade de lei ou ato normativo federal ou estadual e a ação declaratória de constitucionalidade de lei ou ato normativo federal; [...]. (BRASIL, 1988).

Diante da alteração no sistema de arrecadação da contribuição sindical, entidades sindicais propuseram açôes declaratórias de inconstitucionalidade, ADIs, a fim de invalidar a nova redação dos arts. 545, 578, 579, 582, 583, 587 e 602 da CLT, alterados pela Lei n. 13.467/2017, referentes à contribuição sindical facultativa, pelo Supremo Tribunal Federal.

A Confederação Nacional dos Trabalhadores em Transporte Aquaviário e Aéreo, na Pesca e nos Portos - CONTTMAF - foi a primeira entidade sindical a propor a ADI, identificada junto ao STF pelo número 5.794. Por esta ter sido a primeira ADI ajuizada, todas as outras dezoito açóes foram conexas a ela em razão da matéria discutida. Na petiçáo inicial do processo - de número 001203340.2017.1.00.0000 - foi alegada a inconstitucionalidade formal da norma, uma vez que se entendeu vício quanto à lei ordinária alterar lei complementar, excluindo-se um crédito de natureza tributária. $\mathrm{Na}$ página 6 da referida petição, é alegado que: 
Gravame ao $\$ 6^{\circ}$, art. 150 da Constituição: 8. Ainda que náo cuidasse matéria regulada por Lei Complementar, não se poderia descurar que o dispositivo guerreado foi veiculado em lei geral configurando evidente testilha com o $\$ 6^{\circ}$. do art. 150 da Charta do Brasil a exigir, explicitamente, a especificidade, o que demandaria a elaboração de lei tributária específica e exclusiva para tal escopo. 9. Contudo, resta patente que no que na presente quaestio os dispositivos guerreados trazem a eiva da inconstitucionalidade formal também pelo fato de que, ao perfilhar o rito da lei ordinária em sua elaboração, restou descurado o procedimento legislativo adequado, i.e., o da lei complementar para estabelecer a exclusão de um crédito de natureza tributária (BRASIL, 2019).

Diante do pedido de declaração de inconstitucionalidade, arrazoou-se, também o empobrecimento das entidades sindicais e que a abrupta supressão de recursos dos Entes Sindicais inviabiliza a assistência jurídica a seus representados, sendo que ao sindicato náo cabe atender somente aos empregados sindicalizados, mas toda a gama de empregados pertencentes às respectivas categorias profissionais. Assim, o esvaziamento do poder financeiro do sindicato representaria também prejuízos às garantias de direitos sociais fundamentais, como acesso à ampla defesa na esfera juslaborativa. Dessa forma, como pedido principal requereu-se a suspensão da eficácia dos artigos alterados referentes à contribuição sindical facultativa, em medida liminar, bem como a declaração de inconstitucionalidade definitiva destes. Como se observa a seguir:

26. Requer seja julgada procedente a pretensão autoral, mediante (a) a suspensão liminar da eficácia bem como (b) a declaração definitiva de inconstitucionalidade dos dispositivos da Lei que concernem aos indigitados artigos da CLT com sua retirada do ordenamento jurídico pátrio por se revelarem incompatíveis com os Comandos Constitucionais a imporem a ponderaçâo axiológica dos Princípios que a norteiam (CONTTMAF, 2017).

Precedente ao julgamento da ADI, como relatado no parecer emitido pelo STF, no despacho publicado em 1 de agosto de 2018, DJE 153, a Presidência da República, o Senado Federal, a Câmara dos Deputados e a Advocacia Geral da União, ao proferir sobre a constitucionalidade da norma, negaram-lhe vício formal. O relator, em obediência ao art. 12 da Lei n. 9.868/99, submeteu o tema 
a apreciação dos órgãos acima elencados, do Procurador-Geral da República e do Advogado-Geral da Uniáo, para entáo conduzir o processo diretamente ao Tribunal, com a faculdade de julgar definitivamente a ação. Segundo o despacho publicado, os pareceres foram os seguintes:

A Câmara dos Deputados afirmou que "Inegavelmente, a faculdade outorgada pela Constituição aos entes políticos para instituir tributos compreende a competência para, uma vez criados, extingui-los, segundo seus próprios critérios de ordem política e econômica." [...] O Senado Federal, a seu turno, prestou informaçōes e sustentou, em síntese, a impossibilidade jurídica do pedido, eis que, em sua ótica, as alterações promovidas pela norma impugnada elasteceriam garantias dos contribuintes, de modo que não poderiam ser tidas por inconstitucionais. [...] valendo destacar que tornar o "imposto sindical" facultativo terá como consequência sindicatos mais fortes [...]. A Presidência da República, por sua vez, em suas informaçôes, afirmou inexistir qualquer inconstitucionalidade material na opção política tomada pelo Congresso Nacional, pois, na verdade, as alteraçôes promovidas pela Lei n. 13.467/2017 reafirmam os valores sociais protegidos sob a égide constitucional. Destacou, ademais, que a norma impugnada se insere na ambiência da chamada reforma trabalhista "a qual possui como pedra de toque o aprimoramento das relaçốes de trabalho [...]. Argumentou que outras entidades podem prestar assistência jurídica aos trabalhadores e que a lei objurgada não extingue as fontes de financiamento dos sindicatos, [...]. A Advocacia-Geral da Uniăo argumentou pelo não conhecimento da ação direta de inconstitucionalidade e, no mérito, pela improcedência do pedido [...] (BRASIL, 2018b).

Assim, diante de tais pareceres, no julgamento da ADI n. 5.794, em 29 de junho de 2018, por três votos contrários e seis favoráveis à manutenção da contribuição facultativa nos termos da Reforma Trabalhista, o Supremo Tribunal Federal declarou a constitucionalidade da alteração efetivada. Ao longo dos votos, fora debatida a questão de a contribuição sindical ser ou não classificada como imposto - logo, compulsória - e as razóes constitucionais para a manutenção dos artigos da reforma referentes a ela. 


\subsection{Julgamento da ADI n. 5.794}

Durante as discussóes promovidas no julgamento da $\mathrm{ADI}$ em questão, ao decidir sobre a alteração na contribuição sindical, o ministro Marco Aurélio Mello ressaltou que náo considera a contribuição sindical como tributo propriamente dito. "Náo concebo que pessoa jurídica de direito privado seja parte ativa tributária”, sustentou (BRASIL, 2018a). Segundo matéria veiculada pelo site do Supremo Tribunal Federal, em 29 de junho de 2018, na avaliação do ministro:

A contribuição sindical não se enquadra no artigo 149 da Constituição Federal, que trata das contribuiçóes sociais, de intervenção no domínio econômico e de interesse das categorias profissionais ou econômicas. "Não me consta que essa contribuiçẫo vise a atuação do estado. Visa sim a atuação do fortalecimento das entidades sindicais", assinalou. O ministro Marco Aurélio frisou ainda que o artigo $8^{\circ}$ da Carta Magna repete duas vezes que é livre a associação profissional ou sindical e o inciso $\mathrm{X}$ do artigo $7^{\circ}$ prevê a proteção do salário na forma da lei, constituindo crime sua retenção dolosa (BRASIL, 2018a).

Dias Toffoli, um dos ministros que ponderou seu voto a favor da mudança progressiva, afirmou que seria necessário que o Congresso fizesse uma reforma gradativa quanto à contribuição sindical, e não uma abrupta ruptura. Segundo ele, náo seria adequado subverter o sistema sem ter uma regra de transição, sem preparo para a substituição desse financiamento. "Penso que aí está a grande fragilidade do ponto específico que estamos a discutir. Não é possível essa subtração que houve da contribuição sindical sem ter preparado essa transição, sem ter preparado a assunção de mais sociedade civil com menos Estado" (BRASIL, 2018a).

A sugestão de progressividade na implantação da norma, mencionada por Dias Toffoli, por sua vez, talvez pudesse ser mensurada pela própria interpretação do Supremo Tribunal Federal, na modalidade de decisão proferida pela modulação dos efeitos da sentença. Seria um posicionamento ativo conciliatório, visando à equidade entre a mudança na norma vigente durante tantos anos com a repentina ruptura provocada pela nova legislação. Na própria decisão pela constitucionalidade seria passível a ponderação.

Por outro lado, uma questáo diversa que poderia ter sido atacado nas ADIs propostas, e também pela própria recomendação do Supremo Tribunal Federal, é o instituto da vacatio legis, o período que institui a lacuna entre a vigência e a eficácia na norma legal. Contudo, embora fosse de interesse e relevância para o 
equilíbrio nas mudanças ocorridas e a realidade da arrecadação dos sindicatos, essa questáo não fora abordada pelas ADIs.

Por fim, o Supremo Tribunal Federal decidiu pela improcedência dos pedidos, nos seguintes termos:

Decisáo: $\mathrm{O}$ Tribunal, por maioria e nos termos do voto do Ministro Luiz Fux, que redigirá o acórdão, julgou improcedentes os pedidos formulados nas açôes diretas de inconstitucionalidade e procedente o pedido formulado na ação declaratória de constitucionalidade. Vencidos os Ministros Edson Fachin (Relator), Rosa Weber e Dias Toffoli. Ausentes, justificadamente, os Ministros Celso de Mello, Ricardo Lewandowski e Luiz Fux. Presidiu o julgamento a Ministra Cármen Lúcia. Plenário, 29.6.2018 (BRASIL, 2018b).

\section{A modulaçáo dos efeitos da sentença}

Quando um ente legitimado submete uma norma ao controle de constitucionalidade abstrato perante o Supremo Tribunal Federal espera que a norma em questão receba a interpretação conforme preceitua a Constituição Federal vigente. Assim, como leciona Gilmar Mendes, em seu curso de Direito Constitucional, "limita-se o Tribunal a declarar a legitimidade do ato questionado desde que interpretado conforme a Constituição" (MENDES; BRANCO; COELHO, 2017, p. 243).

A Lei n. 9.868/99, que dispóe sobre o processo e julgamento da ação direta de inconstitucionalidade e da ação declaratória de constitucionalidade perante o Supremo Tribunal Federal, no parágrafo único do art. 28, dispóe que os efeitos da decisão do STF serão erga omnes e vinculantes. Por a sentença ser declaratória quanto à constitucionalidade da norma, o Supremo Tribunal não poderá atuar como legislador positivo, isto é, apenas poderá analisar se a lei criada pelo legislador é compatível com a Constituição.

Contudo, consoante a doutrina, as sentenças proferidas podem ser subdivididas além da dicotomia constitucionalidade/inconstitucionalidade. Diante da possível alteração do status quo, visando à modulação dos efeitos da decisão, o STF pode aplicar sentenças intermediárias, normativas, também chamadas de sentenças manipulativas. Segundo leciona Fernandes:

As sentenças intermediárias são o conjunto de decisóes (tipologias) as quais o órgão do Poder Judiciário, que controla a constitucionalidade, relativiza o binômio constitucionalidade/ 
inconstitucionalidade. Ou seja, à luz de fatores políticos econômicos, sociais e jurídicos, o Poder Judiciário passa a trabalhar com técnicas de decisão e efeitos de controle de constitucionalidade que vão além da mera (simples) declaraçáo de constitucionalidade ou inconstitucionalidade de uma lei (FERNANDES, 2017, p. 1574).

A opção por sentenças intermediárias deve ser a via adotada quando se faz necessária a ponderação de interesses em relação à segurança jurídica ou excepcional interesse social, como leciona Fernandes. Um exemplo emblemático citado pelo autor diz respeito ao julgamento da ADI n. 2.240, sobre a criação do Município de Luiz Eduardo Magalhães, no estado da Bahia. Na referida decisão, o Supremo Tribunal Federal declarou a inconstitucionalidade da lei que criou o município, contudo, não declarou nulos seus efeitos, em razão dos prejuízos sabiamente provocados por uma suposta declaração de nulidade da lei. Assim, ao declarar a inconstitucionalidade, ocorreu a modulação dos efeitos da decisão, visto que o STF manteve a vigência do dispositivo legal por até 24 meses para que o legislador estadual pudesse adequar nova lei.

Ainda segundo o autor supracitado, o Informativo n. 576 do STF é um exemplo ainda mais atual da possibilidade de declarar a constitucionalidade ou inconstitucionalidade da lei e ainda assim ponderar seus efeitos. Na decisão da ADI n. 875, e demais açóes conexas quanto ao fundo de participação dos estados que originaram o informativo, foi declarado que:

Fundos de Participação dos Estados: Fixação de Coeficientes e Critérios de Rateio - 4

Por fim, não obstante a Lei Complementar 62/89 não satisfazer integralmente à exigência contida na parte final do art. 161, II, da CF, julgou-se que a sua imediata supressão da ordem jurídica implicaria incomensurável prejuízo ao interesse público e à economia dos Estados, haja vista que o vácuo legislativo poderia inviabilizar, por completo, as transferências de recursos. Em razão disso, fez-se incidir o art. 27 da Lei 9.868/99, e declarou-se a inconstitucionalidade, sem pronúncia da nulidade, do art. $2^{\circ}$, I e II, $\$ \$ 1^{\circ}, 2^{\circ}$ e $3^{\circ}$, e do Anexo Único, da Lei Complementar 62/89, autorizando-se a aplicação da norma até 31.12.2012, lapso temporal que se entendeu razoável para o legislador reapreciar o tema, em cumprimento àquele comando constitucional. Vencido parcialmente o Min. Marco Aurélio, que julgava procedente 
apenas o pleito formulado na ADI por omissáo 1987/DF e, no caso, não aplicava o art. 27 da Lei 9.868/99 (BRASIL, 2010).

Como exemplificado, diante de possíveis e incomensuráveis prejuízos ao interesse econômico dos estados, sem a transferência de recursos, houve a declaração de inconstitucionalidade sem, contudo, a declaração de nulidade de seus efeitos. Dessa forma, evidencia-se a faculdade de o STF se posicionar diante das mudanças propostas ao julgar as ADIs e ao mesmo tempo equilibrar os efeitos da decisão. Portanto, é conciliatório declarar uma norma constitucional, como a alteração dos artigos referentes à contribuição sindical, e, ainda assim, ponderar seus efeitos visando ao não imediatismo na aplicação das normas que puderem alterar abruptamente um modelo econômico já consolidado no ordenamento jurídico nacional. Para isso, é importante analisar alguns modelos de sentenças que tornam possível esse exercício.

\subsection{Sentenças intermediárias}

O conjunto de tipologias de decisóes nas quais os órgãos do Poder Judiciário, ao controlar a constitucionalidade, relativiza o binômio constitucionalidade/ inconstitucionalidade, conforme explica Fernandes, é chamado de sentenças intermediárias. Tais sentenças são proferidas considerando-se fatores políticos, econômicos, sociais e jurídicos. A classificação destas pode se dar conforme os efeitos das decisōes que se pretendem atingir.

Originadas na doutrina italiana, são chamadas de manipulativas as sentenças em que na decisão o órgão responsável pelo controle de constitucionalidade adita normas submetidas à sua apreciação. Assim, a corte modifica diretamente a norma por meio de decisões autoaplicáveis. Em sua obra de Direito Constitucional, quanto às sentenças intermediárias, Fernandes explica dois modelos de sentenças manipulativas, as de efeito substitutivo e as de efeito aditivos:

Assim sendo haveria uma distinção entre as sentenças manipulativas de efeitos aditivos das manipulativas com efeito substitutivo. A primeira espécie verifica-se quando a corte constitucional declara inconstitucional certo dispositivo legal não pelo que expressa, mas pelo que omite, alargando o texto da lei ou seu âmbito de incidência. Já as manipulativas com efeitos substitutivos, por sua vez, são aquelas em que o juízo constitucional declara a inconstitucionalidade da parte em que a lei estabelece determinada disciplina ao invés de outra, 
substituindo a disciplina advinda do poder legislativo por outra, consentânea com o parâmetro constitucional (FERNANDES, 2009).

A partir dessa interpretação, explica o autor, que a norma de conteúdo inconstitucional por insuficiência pode ser ampliada por meio da sentença aditiva. No Brasil, contudo, não há, segundo ele, tradição dessa modalidade de sentença. $\mathrm{Na}$ sentença substitutiva, por vez, a Suprema Corte invalida a norma e a substitui por outra mais adequada. Esse modelo também não é praticado no Brasil, principalmente porque não cabe ao Poder Judiciário ocupar o lugar do Poder Legislativo, pois comprometeria a tripartição de poderes.

Hans Kelsen, na obra Teoria pura do Direito, expóe que toda interpretação da norma deve estar coerente com a moldura na qual o espírito da lei se encaixa, possibilitando mais de uma interpretação, que está além do direito positivado. $\mathrm{O}$ autor analisa:

Se por "interpretação" se entende a fixação por via cognoscitiva do sentido do objeto a interpretar, o resultado de uma interpretação jurídica somente pode ser a fixação da moldura que representa o Direito a interpretar e, consequentemente, o conhecimento das várias possibilidades que dentro desta moldura existem. Sendo assim, a interpretação de uma lei não deve necessariamente conduzir a uma única soluçấo como sendo a única correta, mas possivelmente a várias soluçốes que - na medida em que apenas sejam aferidas pela lei a aplicar - têm igual valor, se bem que apenas uma delas se torne Direito positivo no ato do órgão aplicador do Direito - no ato do tribunal, especialmente. Dizer que uma sentença judicial é fundada na lei, não significa, na verdade, senão que ela se contém dentro da moldura ou quadro que a lei representa - não significa que ela é a norma individual, mas apenas que é uma das normas individuais que podem ser produzidas dentro da moldura da norma geral (KELSEN, 1995).

Assim, ao avaliar-se a constitucionalidade de uma norma, não há apenas que se ater a esta tal qual como escrita, mas sim em qual contexto social, político e econômico, por exemplo, essa norma apresenta-se “emoldurada”. É cognoscível que, para a ciência jurídica, o que se declara como Direito é o complexo além do Direito positivado. Esse é o pensamento norteador que deve amparar as decisôes jurídicas: que a lei não seja apenas tida como determinação legislativa porque fora 
a vontade do legislador, mas que seja analisada conforme necessária e proveitosa ao bem-estar da sociedade, garantindo-lhe a necessária segurança jurídica.

Assim deve ser a interpretação jurídica, além do texto expresso, levar-se em consideração o conhecimento sobre normas de processo de criação jurídica, "normas de Moral, normas de Justiça, juízos de valor sociais que costumamos designar por expressóes correntes como bem comum, interesse do Estado, progresso, etc." (KELSEN, 1995). O autor ainda explicita que a diferença dessa forma de construir-se o Direito e o Direito positivado está no fato de serem interpretaçóes produzidas por diversas operações do conhecimento. "A interpretação feita pelo órgão aplicador do Direito é sempre autêntica. Ela cria Direito" (KELSEN, 1995). Para ele, essa aplicação se torna autêntica quando dotada de caráter geral e assume a forma de lei ou tratado internacional.

Em razão desses apontamentos sobre a interpretação das normas, é relevante destacar, pois, a atuação necessária ao Supremo Tribunal Federal em considerar variadas consequências na aplicação da lei declarada constitucional. Para tanto, importante também avaliar os consequentes prejuízos, não oriundos apenas da declaraçâo de constitucionalidade dos artigos questionados perante a validade da norma, e que o fizesse considerando o caráter social de tais mudanças, e tentasse, por meio de sentenças intermediárias, equilibrar o confronto, exercendo, portanto, a função pacificadora do Direito.

\subsection{Sentenças intermediárias no controle de constitucionalidade}

Para José Adércio Leite Sampaio (1999 apud FERNANDES, 2017, p. 1578), é possível dividir as sentenças intermediárias em dois grupos: O primeiro deles é das sentenças normativas, em que se subdividem as sentenças interpretativas conforme a Constituição; as aditivas; as aditivas de princípio e as substitutivas. O segundo grupo é o das sentenças transitivas ou transacionais, que implicam a relativização e se subdividem em sentenças de inconstitucionalidade sem efeito ablativo; as com ablação diferida; as de apelo ou apelativas e as de aviso.

Em razão de o primeiro grupo, como já explicitado, não ser adotado como prática recorrente no Brasil, o trabalho limitar-se-á à análise das possibilidades do segundo grupo para avaliar a sentença dada na ADI n. 5.794.

Primeiramente, vale ressaltar que a possibilidade de sentença transacional foi positivada com a Lei n. 9.868/99, que regulamenta o trâmite das ADIs e ADCs, em cujo art. 27 é proclamada a possível restrição aos efeitos da lei, como se observa:

Art. 27. Ao declarar a inconstitucionalidade de lei ou ato normativo, e tendo em vista razóes de segurança jurídica ou de 
excepcional interesse social, poderá o Supremo Tribunal Federal, por maioria de dois terços de seus membros, restringir os efeitos daquela declaração ou decidir que ela só tenha eficácia a partir de seu trânsito em julgado ou de outro momento que venha a ser fixado (BRASIL, 1999).

Misabel Derzi, ao comentar o referido artigo sobre o poder de decisão e ponderação do Supremo Tribunal Federal, analisa que a diferenciação entre decisóes de açôes declaratórias deve ser dada considerando-se presente, passado e futuro no qual ensejam a decisão. Segundo a autora, "A obrigatoriedade de antecipação do futuro ou de sua projeção está implícita em toda decisão" (DERZI, 2009). Ela ainda explica que este é o pressuposto das súmulas vinculantes e sem a fundamentação analítica adequada das sentenças proferidas não há, nas palavras dela "expectativas legítimas de normatividade, essenciais à segurança, nem tampouco exigir a observância dos critérios legais” (DERZI, 2009). Nesse sentido, a autora destaca que:

A Lei 9868/01 não reduz, anula ou subtrai da decisão da Corte Suprema o que a ela é inerente. Se a Constituição Federal não estabelece claramente os efeitos da decisão judicial, nos casos da declaraçáo de inconstitucionalidade, em abstrato ou nos casos concretos, então, os efeitos da decisão podem ser pesados e limitados à vista de critérios de alta relevância, em especial por razóes de segurança jurídica, que imantam a própria Constituição (DERZI, 2009, p. 9).

A partir desse pensamento, reforça-se a concepção da necessidade de as decisóes proferidas pelo STF considerarem os reflexos sociais que trarão. Logo, embora seja pertinente a discussão sobre os limites da atuação do Superior Tribunal no tocante às decisôes que implicam muitas vezes a esfera legislativa, é de extrema relevância que haja ponderação dos efeitos da sentença para adequar-se à proteção social, visando-se a realidade fática além da dicotomia constitucional/ inconstitucional.

Quanto às razóes de segurança jurídica, norteadas por princípios constitucionais, dizem respeito à confiabilidade que a sociedade pretende exercer quanto à proteção que objetiva receber de um Estado Democrático de Direito. Humberto Ávila, ao avaliar o instituto da segurança jurídica em perspectiva dinâmica e intertemporal, explica que pensar em segurança jurídica com o sentido de imutabilidade conduz à interpretação por vezes pejorativa de tratar-se uma 
petrificação do Direito. Por outro lado, contudo, pode-se entender a segurança jurídica como "estabilidade na mudança", isto é, como a proteção de situaçôes subjetivas já garantidas individualmente e a exigência de continuidade do ordenamento jurídico por meio de regras de transição e de cláusulas de equidade (ÁVILA, 2011).

Para o autor, essa segunda concepção implica uma alteraçáo estável ou racional, sem modificaçóes abruptas. Assim, prepara-se a sociedade para as mudanças gradativas às quais será possível adaptar-se. Ademais, o doutrinador explica que a segurança jurídica com vista ao futuro está relacionada à previsibilidade e calculabilidade:

Quanto à eficácia futura do Direito, pode-se, heuristicamente, também esboçar duas concepçôes. De um lado, pode-se sustentar que a segurança jurídica prescreve a total capacidade de antecipar as consequências jurídicas da conduta (própria ou alheia). $\mathrm{O}$ termo "previsibilidade" e a expressâo "certeza absoluta" denotam esse sentido. Nessa significação, a segurança jurídica garante o direito de o particular, com exatidão, conhecer, hoje, o Direito de amanhâ, antecipando o conteúdo da decisão futura que irá qualificar juridicamente o ato hoje praticado. De outro lado, no entanto, pode-se arguir que a segurança jurídica apenas exige a elevada capacidade de prever as consequências jurídicas de atos ou fatos pela maioria das pessoas. Nessa acepção, a segurança jurídica garante que se possa, em larga medida, antecipar alternativas interpretativas e efeitos normativos de normas jurídicas. A palavra mais correta para denotar esse sentido, em vez de "previsibilidade" (Voraussehbarkeit), é "calculabilidade" (Berechenbarkeit). Calculabilidade significa, pois, a capacidade de o cidadão prever, em grande medida, os limites da intervenção do Poder Público sobre os atos que pratica, conhecendo antecipadamente o âmbito de discricionariedade existente para os atos estatais (ÁVILA, 2011).

Nesse sentido, tanto por possibilidade legal do art. 27 da Lei n. 9.868/01, quanto pela interpretação jurisprudencial, reforça-se a hipótese de que, ao declarar a constitucionalidade dos artigos referentes à facultatividade da contribuição sindical, alterando-lhe o caráter tributário para meramente contributivo, o Supremo Tribunal Federal, no julgamento da ADI n. 5.794, deveria exercer o papel mediador da transição visando promover à segurança jurídica. Com maior prazo 
de adaptação, aos sindicatos de trabalhadores seriam permitidas alternativas de estudo de planejamento referente às funçôes sindicais dependentes dessa cobrança. Ademais, ressalta-se ainda a participação estatal nessas verbas para garantir as funçôes do estado de apoio ao trabalhador, por meio do fundo de amparo. Assim, os trabalhadores não apenas sofreram impacto da decisão repentina provocada pela reforma trabalhista, com a descapitalização dos sindicatos, mas também o Estado sofreu perdas em sua capacidade de promover proteção ao trabalho, comprometendo-se a execução de um direito e garantia fundamental, previsto no art. 6º da Constituição Federal de 1988.

Ante essas reflexóes sobre a relevância da segurança jurídica no panorama de transformaçóes legais, e consequentemente sociais diante de novos atos normativos, passa-se a apresentar as tipologias de sentenças intermediárias e avaliar possibilidades de aplicação delas para ponderar e equilibrar os efeitos da lei declarada constitucional.

\subsubsection{Sentenças de inconstitucionalidade sem efeito ablativo}

A declaração de inconstitucionalidade sem efeito ablativo é uma modalidade alemã em que se reconhece a inconstitucionalidade da norma, contudo, em nome da segurança jurídica, não há pronúncia de nulidade dos efeitos da lei. Assim, provoca uma decisão ex-nunc, isto é, sem efeitos retroativos. É válido ressaltar a observação do professor José Adércio Leite Sampaio apud Fernandes, que a declaração de constitucionalidade sem efeito ablativo deve ser acompanhada de proibição da aplicação da lei inconstitucional, caso contrário, torna-se uma sentença nula em seu sentido. Um exemplo de declaração de inconstitucionalidade sem efeito ablativo, portanto, foi no caso já mencionado acerca da criação do município baiano, na $\mathrm{ADI}$ n. 2.240, que declarou a lei que criou o município inconstitucional, contudo, não anulou a criação deste.

\subsubsection{Sentença de inconstitucionalidade com ablação diferida}

As decisóes de nulidade, em regra, são ex-tunc, isto é, retroagem para aplicação dos efeitos da lei declarada constitucional ou inconstitucional. Contudo, em razão da supremacia da Constituição, avaliando-se os efeitos da lei, num exercício de ponderaçáo entre a nulidade e as razóes de segurança jurídica e excepcional interesse social, é passível a aplicaçáo gradual da lei, contrabalanceando-se outros valores envolvidos. Fernandes esclarece que essa alternativa, ablação diferida, não é uma sentença intermediária propriamente dita, mas por força da modulação dos 
efeitos do art. 27 da Lei n. 9.869/99 tal modalidade de sentença pode ser incluída nesse rol de maneira náo rigorosa.

\subsubsection{Sentenças apelativas e sentenças de aviso}

Também chamadas de sentenças de apelo, declaração de constitucionalidade progressiva ou de constitucionalidade provisória, nesse modelo de sentença, o órgão jurisdicional apenas reconhece a constitucionalidade da norma, mas adverte o legislador quanto à necessidade de mudanças normativas para que futuramente elas não incorram em inconstitucionalidade. Sampaio, segundo Fernandes, critica essa modalidade de sentença por ser apenas uma exortação ao legislador.

As sentenças de aviso, por sua vez, sinalizam uma possível mudança jurisprudencial futura, mas com a ressalva de o novo precedente não ser aplicado no caso sub júdice. Um exemplo, dado por Fernandes, dessa modalidade de sentença ocorreu no RE n. 630.733, em 2013, quando o STF manifestou-se sobre possibilidade de segunda chamada para testes de aptidáo física em concurso público futuramente, mas que tal alteração não teria validade no caso em comento.

\subsection{Críticas quanto às sentenças intermediárias}

Não obstante a positivação dos possíveis efeitos das sentenças no art. 27 da Lei n. 9.868/99, há críticas consideráveis quanto à aplicação das sentenças intermediárias. Para Sampaio, consoante Fernandes, nas sentenças normativas o Tribunal Constitucional peca pelo excesso de atuação, ao passo que, nas sentenças transitivas, suas atuaçóes não têm adequação na prestação jurisdicional por serem frágeis. Ainda segundo Fernandes, para o professor Álvaro Ricardo Souza Cruz, ambos os modelos de decisão, normativas ou transitivas, exorbitam a função do Poder Judiciário que é limitada à de intérprete constitucional.

Apesar das críticas, é relevante considerar que, no controle de constitucionalidade, é função do Poder Judiciário averiguar a legalidade das leis, tendo como parâmetro a Carta Constitucional, mas também avaliar os efeitos dela, pois é também para isso que existem as ações de controle de constitucionalidade, ADI, ADC e ADPF. Dessa forma, nas sentenças prolatadas poderiam ser aplicados princípios do direito intertemporal, em regras de transição.

No caso do julgamento da ADI n. 5.794, a oportunidade de se aplicar a sentença intermediária, transitivas, possibilitaria a ampliação do debate jurídico sobre a contribuição sindical, relativizando a norma imposta pela Reforma Trabalhista e resguardando os sindicatos bem como os trabalhadores em seu 
âmbito de proteção constitucional. Ademais, o Supremo Tribunal Federal poderia garantir a segurança jurídica na implantação progressiva das normas, a partir das sentenças dessa tipologia, relativizando tanto a supremacia constitucional quanto os demais valores axiológicos envolvidos e preservando a segurança jurídica. Ainda mantendo a declaração de constitucionalidade da norma alterada, em uma sentença apelativa, poderia o Supremo solicitar ao legislador ampliação do prazo de vacatio legis para a implantaçáo dos efeitos da lei, evitando-se, assim, o fator surpresa que acometeu os sindicatos, trazendo-lhes evidentes prejuízos.

\section{Do prazo da Vacatio Legis como moderador dos efeitos da declaraçáo de constitucionalidade da norma}

Vacatio Legis é uma expressão latina que significa vacância da lei, é, portanto, o nome que se dá ao lapso entre a vigência e a validade da norma jurídica. Nesse ínterim, uma norma pode já estar publicada, mas não surtir efeitos até uma determinada data para que haja lacuna temporal para a adaptação da norma à realidade sociológica. Enquanto isso, prevalecem as normas antecedentes à mudança. Quanto maior a mudança promovida no status quo da sociedade por meio da alteraçáo da lei, maior deve ser o prazo da vacatio legis para os efeitos da nova norma.

No julgamento da ADI n. 5.794, um dos ministros que ponderou seu voto a favor da mudança progressiva, Dias Toffoli afirmou que seria necessário que o Congresso fizesse uma reforma gradativa quanto à facultatividade na cobrança da contribuição sindical, e não uma abrupta ruptura. Segundo ele, não seria adequado subverter o sistema sem ter uma regra de transição, sem preparo para a substituição desse financiamento. Como afirma: "Penso que aí está a grande fragilidade do ponto específico que estamos a discutir. Não é possível essa subtração que houve da contribuição sindical sem ter preparado essa transição, sem ter preparado a assunção de mais sociedade civil com menos Estado" (BRASIL, 2018a).

A progressividade mencionada pelo ministro, por sua vez, poderia ser mensurada pela própria interpretação do Supremo Tribunal Federal. Uma das possibilidades de implantar a alteração quanto ao caráter tributário até então vigente e com a consequente perda na arrecadaçáo da contribuiçấo sindical poderia ser solucionada por meio da alteração do período da vacatio legis, por meio de uma sentença intermediária transitiva apelativa, conforme abordado no capítulo anterior.

Embora o tema sobre o prazo para a implantação dos efeitos da lei não seja muito discutido, é de extrema relevância avaliar que a validade da norma jurídica 
depende estritamente do instituto vacatio legis. Gonçalves, citado por Brum, sobre as regras gerais do Código Civil explica que o prazo de vacatio legis de uma lei é "o intervalo entre a data de sua publicação e a sua entrada em vigor" (BRUM, 2006). Nesse prazo, a norma jurídica existe e é válida, contudo não tem eficácia, pois está em período de vacância. Conforme define Ulhôa Coelho (2003 apud BRUM, 2006, p. 1):

\begin{abstract}
Vigência é aptidão genérica de produzir efeitos juridicamente válidos. Após a publicação na imprensa oficial a lei existe, mas isso nâo significa que esteja já produzindo efeitos. Em outros termos, ela já é conhecida, mas não pode ainda ser aplicada. Assim, se estabelece a obrigação de determinada conduta, as pessoas já podem ter conhecimento de seu conteúdo, mas ainda não estão obrigadas a se comportarem em consonância com os seus preceitos. Quem atua em desconformidade com o prescrito em lei existente que ainda não entrou em vigor não pode sofrer nenhuma sanção.
\end{abstract}

Assim sendo, uma norma pode estar publicada e ainda não produzir efeitos. Como exemplo, há o período de um ano de vacatio legis para a Lei n. 10.406 de 10 de Janeiro de 2002, o Código Civil: "Art. 2.044. Este Código entrará em vigor 1 (um) ano após a sua publicação". Na mesma lógica, o Código de Processo Civil de 2015 também teve estabelecido o prazo de um ano para a entrada em vigor da nova lei: "Art. 1045. Este Código entra em vigor após decorrido 1 (um) ano da data de sua publicação oficial".

Embora haja críticas quanto ao desrespeito ao art. $8^{\circ}$ da LC n. 95/98, que prevê a determinação do prazo em dias, não em ano ou meses, o que se procura ressaltar neste trabalho é que o tempo estipulado para que a lei produza efeitos é relevante instrumento a ser analisado. É evidente que os efeitos de uma norma a ser aplicada com maior prazo, quando gera bruscas alteraçóes na legislação e traz em si efeitos sociais, serấo de uma norma menos danosa quando ocorrer o vigor $\mathrm{e}$ a consequente produção de efeitos jurídicos.

Dessa forma, ponderando-se o prazo de validade da lei evitar-se-á a abrupta ruptura com a legislação vigente, muitas vezes já arraigada na tradição. Isso ocorre porque o tempo de adaptação às novas normas, conforme determina a Lei Complementar n. 95/98, que dispóe sobre a elaboração, a redação, a alteração e a consolidaçáo das leis, deve ser razoável, e, assim, consequentemente, também privilegiar o bem-estar social, indicando expressamente o período de vacância em dias, para que da lei se tome conhecimento. 
Não obstante a LC n. 95/98 determinar o prazo para conhecimento e aplicaçáo da lei atualizada, quando se trata de efeitos das normas ao longo do tempo, sua vigência, eficácia e aplicação, há situaçôes de intervençáo no lapso temporal pelos Tribunais. Por exemplo, na seara trabalhista, quando da alteração da prescriçấo do FGTS, de trintenária pra quinquenal, ao avaliar a aplicação da Súmula 362 do TST (Tribunal Superior do Trabalho), o STF julgou que o prazo prescricional de 30 anos era inconstitucional, ARE709212/DF. Então, o próprio STF modulou-lhe os efeitos dessa decisão, conforme sugestão do relator - ministro Gilmar Mendes - para aplicar a norma gradativamente. Como se observa a seguir:

[...] É certo que, na citada decisão, foi declarada a inconstitucionalidade dos artigos $23, \$ 5^{\circ}$, da Lei $8.036 / 90$ e 55 do Decreto 99.684/80 "na parte em que ressalvam o 'privilégio do FGTS à prescrição trintenária', por violarem o disposto no art. 70, XXIX, da Carta de 1988”. Contudo, em atenção à segurança jurídica e à boa-fé objetiva, seus efeitos foram modulados de modo a salvaguardar especialmente os diretos dos trabalhadores cujo prazo trintenário já estava em curso à época da decisão, conforme esclarecimento ofertado inclusive pelo Ministro Gilmar Mendes, relator, nos termos a seguir: "A modulaçáo que se propóe consiste em atribuir à presente decisão efeitos ex nunc (prospectivos). Dessa forma, para aqueles cujo termo inicial da prescrição ocorra após a data do presente julgamento, aplicase, desde logo, o prazo de cinco anos. Por outro lado, para os casos em que o prazo prescricional já esteja em curso, aplica-se o que ocorrer primeiro: 30 anos, contados do termo inicial, ou 5 anos, a partir desta decisão. Assim se, na presente data, já tenham transcorrido 27 anos do prazo prescricional, bastarão mais 3 anos para que se opere a prescrição, com base na jurisprudência desta Corte até então vigente. Por outro lado, se na data desta decisão tiverem decorrido 23 anos do prazo prescricional, ao caso se aplicará o novo prazo de 5 anos, a contar da data do presente julgamento (BRASIL, 2017b).

Como demonstrado, em nome da segurança jurídica e da boa-fé objetiva, ao avaliar a inconstitucionalidade da prescrição trintenária do FGTS, passando então para a prescrição quinquenal, entendendo que o FGTS se amolda ao mesmo prazo dos direitos trabalhistas previstos na Constituição Federal, o Supremo Tribunal Federal modulou os efeitos da súmula do TST e, assim, houve nova redaçáo para esta: 
Súmula n. 362 do TST

FGTS. PRESCRIÇÃO (nova redação) - Res. 198/2015, republicada em razão de erro material - DEJT divulgado em 12, 15 e 16.06.2015 - I - Para os casos em que a ciência da lesão ocorreu a partir de 13.11.2014, é quinquenal a prescrição do direito de reclamar contra o não-recolhimento de contribuição para o FGTS, observado o prazo de dois anos após o término do contrato; II - Para os casos em que o prazo prescricional já estava em curso em 13.11.2014, aplica-se o prazo prescricional que se consumar primeiro: trinta anos, contados do termo inicial, ou cinco anos, a partir de 13.11.2014 (STF-ARE-709212/DF) (BRASIL, 2015).

Embora o prazo para prescrição do FGTS e a contribuição sindical facultativa sejam temas diferentes, mas considerando-se que ambos pertencem à seara trabalhista, e que o segundo manifesta-se ainda mais prejudicial por tratar-se de todos os grupos sindicais, analogamente ao julgamento da inconstitucionalidade do prazo trintenário, o Supremo Tribunal Federal poderia também ter modulado o efeito da brusca alteração na contribuição sindical facultativa, como ponderou o ministro Dias Toffoli, na ocasiáo do julgamento da ADI n. 5.794.

Na Lei de Introdução às Normas do Direito Brasileiro, no art. 6, é declarado que "a Lei em vigor terá efeito imediato e geral, respeitados o ato jurídico perfeito, o direito adquirido e a coisa julgada” (BRASIL, 1942). Embora o imediatismo seja o sentido da norma em questão, prazo para a aplicação da Lei n. 13.467/2017 foi estritamente exíguo, e, como agravante, o legislador náo fez previsão alguma sobre as normas de direito intertemporal. Nessa lacuna, cabe à doutrina e à jurisprudência adequar a transição normativa à prática social. Diante de uma norma de direito trabalhista que desprivilegia os trabalhadores e também as organizaçôes sindicais dos quais fazem parte, cabe uma postura mais ativa dos órgãos aplicadores da lei, sobretudo o Supremo Tribunal Federal, que guarda em sua função primordial, a garantia da obediência à Constituição Federal, em toda a sua eficácia.

Não obstante, é pertinente à crítica a constante situação do ativismo judicial, o qual, inúmeras vezes, compromete o princípio da separação dos Poderes. Contudo, deve-se considerar que os direitos trabalhistas têm natureza de direitos fundamentais sociais, por isso, é admissível nessa seara uma postura ativista do Poder Judiciário. Isso, sobretudo se considerarmos que, a uma só vez, várias normas protetivas dos direitos dos trabalhadores foram alteradas, e, além do prejuízo individual, há o dano coletivo ao qual às entidades sindicais estâo sujeitas devido à fragilização na arrecadaçáo financeira, porque a nova legislaçáo desconsiderou 
que estas são entidades constitucionalmente vocacionadas à proteção dos direitos trabalhistas.

\section{Consideraçóes finais}

A Lei n. 13.467/2017, popularmente chamada de Reforma Trabalhista, alterou diversos dispositivos que regulamentam as relaçóes de trabalho. Entre eles, houve mudança na contribuição sindical, que, por força da nova legislação, passou a ser facultativa, perdendo seu caráter compulsório, e, portanto, tributário, nos termos do art. $3^{\circ}$ do CTN. Diante das alteraçóes e dos prejuízos iminentes, sindicatos de trabalhadores ajuizaram dezenove açóes declaratórias de inconstitucionalidade, ADIs, perante o Supremo Tribunal Federal, alegando, predominantemente vício formal da nova legislação.

No julgamento da ADI n. 5.794, à qual foram conexas as demais, o Supremo Tribunal Federal limitou-se a declarar a constitucionalidade da norma, numa decisão claramente política e isenta de reflexóes sobre os efeitos que uma mudança repentina traria para os sindicatos e para os trabalhadores, afiliados a eles ou não. Contudo, diante da relevância do objeto em questão, caberia uma postura mais crítica e proativa do STF, uma vez que a mera declaração quanto à constitucionalidade/inconstitucionalidade da norma sub júdice gera efeitos de grandes proporçóes por se tratar de direito coletivo do trabalho, logo, de grande impacto social.

Assim sendo, a postura mais adequada a ser adotada pelo Supremo Tribunal Federal, pensando no bem-estar coletivo, poderia ser, além de declarar a constitucionalidade, optar pela modulação dos efeitos da sentença, quanto à vigência da lei no tempo. Assim, por meio de sentença intermediária, garantiria a segurança jurídica na implantação progressiva das novas normas, uma vez que o legislador não impôs regras de transição para o direito intertemporal. Ademais, caberia também ao STF indicar ao legislador a possibilidade de alteração no prazo para a aplicação das novas normas.

O prazo estipulado para a vacatio legis foi exíguo quanto à significância das normas alteradas, por isso, caberia um prazo maior, como ocorreu com a vigência do Código Civil de 2002 e com o novo Código de Processo Civil de 2015, ambos com o prazo de vacância equivalente a 12 (doze) meses. Nesse sentido, o STF também poderia tanto recomendar a alteração do dispositivo para evitar o abrupto prejuízo para as instituiçóes sindicais quanto ele mesmo ponderar os efeitos da decisão na sentença. 
Embora haja críticas quanto à usurpação do poder de legislar pelo poder judiciário, em um exercício de ponderação entre as perdas sofridas e considerandose os valores constitucionais axiológicos envolvidos, deve prevalecer a medida menos gravosa. Seria, então, possível conciliar a redução dos prejuízos sofridos pelos sindicatos, sobretudo os sindicatos de trabalhadores, e a atualização da legislaçáo trabalhista, concedendo tempo para que os sindicatos efetivamente trabalhassem junto aos sindicalizados para garantir a sua força sindical.

Ante os argumentos expostos, retomam-se as questôes inicialmente propostas nesta pesquisa: "caberia ao Supremo Tribunal Federal modular os efeitos da declaraçáo de constitucionalidade da nova lei e recomendar um novo prazo de vacância a fim de contribuir com a não descapitalização dos sindicatos? É cabível essa medida como um dos papéis institucionais do Poder Judiciário?”.

A conclusão a que se chega é que sim, considerando-se as técnicas de interpretação das leis, o contexto social em que a norma está inserida, a possibilidade de proferir sentenças intermediárias e a segurança jurídica que deve ser coerente com os dogmas do Direito, seria pertinente maior ativismo do Poder Judiciário, representado pelo Supremo Tribunal Federal no caso da Ação Declaratória de Constitucionalidade por força da própria Constituição Federal de 1988. Isso, não para declarar a inconstitucionalidade da contribuiçấo sindical ter-se tornado facultativa, mas sim para ponderar meios menos danosos de aplicá-la perante as entidades sindicais.

\section{Referências}

ÁVILA, H. B. Segurança Jurídica: entre permanência, mudança e realização do Direito Tributário. São Paulo: Malheiros, 2011.

ANDRADE, L. G.; PAVELSKI, A. P. Reflexos da Reforma Trabalhista na contribuição sindical: tributo que persiste com caráter obrigatório. Revista Eletrônica Reforma Trabalhista III - TRTPR, Curitiba, v. 7, n. 63, p. 34-45, nov. 2017. Disponível em: <http://simepar.org.br/wp-content/uploads/2017/11/ ARTIGO-ASSESSORIA-JURIDICA-1.pdf>. Acesso em: 25 set. 2018.

BRASIL. Câmara dos Deputados. Decreto-Lei n. 2.377, de 8 de julho de 1940. Dispóe sobre o pagamento e a arrecadação das contribuiçóes devidas aos sindicatos pelos que participam das categorias econômicas ou profissionais representadas pelas referidas entidades. Disponível em: <https://www2.camara.leg.br/legin/fed/ declei/1940-1949/decreto-lei-2377-8-julho-1940-412315-publicacaooriginal-1pe.html>. Acesso em: 1 out. 2018. 
BRASIL. Câmara dos Deputados. Decreto-Lei n. 4.657, de 4 de setembro de 1942. Lei de Introdução às Normas do Direito Brasileiro; Lei de Introdução ao Código Civil. Disponível em: <https://www2.camara.leg.br/legin/fed/declei/1940-1949/ decreto-lei-4657-4-setembro-1942-414605-norma-pe.html>. Acesso em: 1 nov. 2018.

BRASIL. Presidência da República. Casa Civil. Subchefia para Assuntos Jurídicos. Lei n. 4.589, de 11 de dezembro de 1964. Extingue, a Comissão do Impôsto Sindical, a Comissão Técnica de orientação Sindical, cria órgãos no Ministério do Trabalho e Previdência Social, e dá outras providências. Disponível em: <http:// www.planalto.gov.br/ccivil_03/leis/L4589.htm>. Acesso em: 1 out. 2018.

BRASIL. Presidência da República. Casa Civil. Subchefia para Assuntos Jurídicos. Lei n. 5.172, de 25 de outubro de 1966. Dispóe sobre o Sistema Tributário Nacional e institui normas gerais de direito tributário aplicáveis à União, Estados e Municípios. Diário Oficial [da] República Federativa do Brasil, Brasília, 27 out. 1966. Disponível em: <http://www.planalto.gov.br/ccivil_03/leis/15172.htm>. Acesso em: 1 out. 2018.

BRASIL. Presidência da República. Casa Civil. Subchefia para Assuntos Jurídicos. Constituição da República Federativa do Brasil. Brasília, DF: 1988. Disponível em: $<$ http://www.planalto.gov.br/ccivil_03/constituicao/constituicao.htm>. Acesso em: 1 out. 2018.

BRASIL. Presidência da República. Casa Civil. Subchefia para Assuntos Jurídicos. Lei n. 9.868, de 10 de novembro de 1999. Brasília, DF: Presidência da República, 1999. Dispóe sobre o processo e julgamento da ação direta de inconstitucionalidade e da ação declaratória de constitucionalidade perante o Supremo Tribunal Federal. Disponível em: <http://www.planalto.gov.br/ccivil_03/LEIS/L9868.htm>. Acesso em: 1 nov. 2018.

BRASIL. Supremo Tribunal Federal. Informativo STF n. 576, 22-26 fev. 2010. Disponível em: <http:/www.stf.jus.br/arquivo/informativo/documento/ informativo576.htm> Acesso em: 2 nov. 2018.

BRASIL. Tribunal Regional do Trabalho. 6a Região. Ementa: prescrição aplicável. Trintenária. Modulação dos efeitos. Decisão STF-ARE-709212, 13 nov. 2014. Disponível em: <http://www.trt6.gov.br/portal/sites/default/files/ documents/0000077230.2016.5.06.0021.pdf>. Acesso em: 1 out. 2018.

BRASIL. Tribunal Superior do Trabalho. Súmula n. 362 do TST, 2015. Disponível em <http://www3.tst.jus.br/jurisprudencia/Sumulas_com_indice/Sumulas_ Ind_351_400.html\#SUM-362>. Acesso em: 28 set. 2018. 
BRASIL. Consolidação das leis do trabalho - CLT e normas correlatas. Brasília, DF: Senado Federal, Coordenação de Edições Técnicas, 2017a. Disponível em <http://www2.senado.leg.br/bdsf/bitstream/handle/id/535468/clt_e_normas_ correlatas_1ed.pdf>. Acesso em: 20 out. 2018.

BRASIL. Tribunal Regional do Trabalho. 6a Região. Recurso Ordinário : RO 00007723020165060221 - Inteiro Teor. JusBrasil, 29 mar. 2017b. Disponível em: <https://trt-6.jusbrasil.com.br/jurisprudencia/444664948/recurso-ordinarioro-7723020165060221/inteiro-teor-444664960>. Acesso em: 1 set. 2018.

BRASIL. Supremo Tribunal Federal. STF declara constitucionalidade do fim da contribuição sindical obrigatória. Notícias STF, 29 jun. 2018a. Disponível em: $<$ http://www.stf.jus.br/portal/cms/verNoticiaDetalhe.asp?idConteudo=382819>. Acesso em: 1 set. 2018.

BRASIL. Supremo Tribunal Federal. Medida Cautelar na Ação Declaratória de Inconstitucionalidade 5.794. MC/DF. Brasília, DF, 2018b. Disponível em: $<$ https://www.conjur.com.br/dl/fachin-fim-contribuicao-sindical-acabar.pdf>. Acesso em: 2 set. 2018.

BRASIL. Supremo Tribunal Federal. ADI 5794: processo número único 001203340.2017.1.00.0000. Brasília, DF: STF, 2019. Disponível em: <https://portal.stf. jus.br/processos $/$ detalhe.asp?incidente=5288954>. Acesso em: 1 out. 2018.

BRUM, A. B. A “vacatio legis" posterior à Lei Complementar n. 95/98 e seus reflexos na vigência do Código Civil e da Lei n. 11.232/05. Jus Navigandi, Teresina, ano 10, n. 1150, 25 ago. 2006. Disponível em: <http://jus2.uol.com.br/ doutrina/texto.asp?id=8842>. Acesso em: 25 set. 2018

DELGADO, M. G.; DELGADO, G. N. A reforma trabalhista no Brasil: com os comentários à Lei n. 13.467/2017. São Paulo: LTr, 2017.

DERZI, M. A. M. Modificaçôes da Jurisprudência no Direito Tributário: proteção da confiança, boa-fé objetiva e irretroatividade como limitaçóes constitucionais ao poder de tributar. São Paulo: Noeses, 2009.

FERRAZ, L.; GODOI, M. S.; SPAGNOL, W. B. Curso de direito financeiro e tributário. 2. ed. Belo Horizonte: Fórum, 2017.

FERNANDES, B. G. Curso de Direito Constitucional. Salvador: JusPodivm, 2017. KELSEN, H. Teoria pura do Direito. São Paulo: Martins Fontes, 1995. 
MARTINS, I. G. S. Contribuição no interesse das categorias: natureza jurídica e a função delegada. Revista Jurídica UNIARAXÁ, Araxá, v. 20, n. 19, p. 189-206, ago. 2016. Disponível em <http://www.uniaraxa.edu.br/ojs/index.php/juridica/ article/view/519>. Acesso em: 5 fev. 2018.

MENDES, G. F.; BRANCO, P. G. G.; COELHO, I. M. Curso de Direito Constitucional. 4. ed. São Paulo: Saraiva, 2009.

MENDES, G. F.; BRANCO, P. G. G. Curso de direito constitucional. 7. ed. rev. e atual. São Paulo: Saraiva, 2012. 